\title{
Effect Of Corporate Governance On The Association Between Book-Tax Differences And Audit Quality: Evidence From Korea
}

\author{
Hyunmin Oh, Hanyang Woman University, South Korea \\ Sambock Park, Bucheon University, South Korea \\ Soonwook Hong, Hanyang University, South Korea
}

\begin{abstract}
We investigate whether auditors input additional audit hours according to the sizes of book-tax differences (hereinafter BTD) and request additional audit fees for additional audit hours. In addition, the interaction effects of corporate governance on the relationships between BTD and audit hours/audit fees are examined using the total corporate governance (TCG) scores, data from the Korea Corporate Governance Service (KCGS). We predict that since auditors have the incentive and ability to consider BTD, audit hours and audit fees will increase when BTD are larger. Empirical results of our study are as follows. First, BTD and audit hours (LnAH) show a negative (-) association that is not statistically significant. Second, audit fees (LnAF) were shown to increase along with BTD. This can be interpreted as a result of requests for additional audit fees for increased audit risks due to individual firms' BTD. Third, the interaction effect of corporate governance on the relationship between BTD and audit hours $(\mathrm{LnAH})$ showed a positive (+) association, but the association was not statistically significant. Fourth, the interaction effect of corporate governance on the relationship between BTD and audit fees (LnAF) showed a statistically significant positive (+) association. This be understood as meaning that firms with better governance make more efforts for financial reporting in order to maintain their reliability in the market. This study contributes to the literature in several important aspects. First, it empirically demonstrates whether auditors properly reflect BTD on audit risks. Next, our study is analyzes the effects of corporate governance on the relationship between BTD and audit hours/audit fees using the total corporate governance (TCG) scores presented by the Korea Corporate Governance Service (KCGS). Finally, our findings empirically showed social proof function of accounting audits as a strategy to reduce information risks.
\end{abstract}

Keywords: Book-Tax Differences; Audit Hours; Audit Fees; Audit Risks; Corporate Governance

\section{INTRODUCTION}

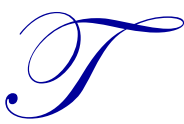

his study investigates whether auditors input additional audit hours according to the sizes of book-tax differences (hereinafter BTD) and request additional audit fees for the additional audit hours. In addition, the interaction effects of corporate governance on the relationships between book-tax differences (BTD) and audit hours/audit fees are examined using the total corporate governance (TCG) scores, data from the Korea Corporate Governance Service (KCGS). Prior research has examined the association between booktax differences (BTD) and measures of earnings quality and/or tax avoidance. ${ }^{1}$

Financial accounting provides useful information for decision making by information users external to firms such as investors and creditors. On the other hand, tax accounting is aimed to provide information necessary to pay taxes based on tax laws to tax authorities. Thus, book-tax differences (BTD) become to occur. There are two types of

${ }^{1}$ For example, larger book-tax differences are associated with less persistence (Hanlon, 2005), target beating (Phillips et al., 2003), lower growth (Lev and Nissim, 2004), and lower bond ratings (Ayers et al., 2009). 
book-tax differences. First, temporary book-tax differences are differences in the timing of accrual recognition between book and taxable income (e.g., warranty reserve, bad debt reserve, depreciation, etc.). Temporary differences provide information about the quality of pretax accounting accruals (Hanlon, 2005; Hanlon and Heitzman, 2010). Second, permanent book-tax differences are differences between book and taxable income that never reverse. Permanent differences are not often suspected to be indicators of earnings quality in terms of accruals manipulation because they are not related to the timing of accrual recognition.

Because the possibility for managers to exercise arbitrariness is much higher in the case of book incomes compared to taxable incomes, BTD reflects considerable information regarding managers' opportunistic discretion on accounting earnings or the quality of book incomes (Palepu et al., 2000; Phillips et al., 2003). The literature on BTD provides evidence consistent with large BTD indicating lower "earnings quality", which indicates information risks, that may result in a reduction of earnings quality. Thus, information asymmetry between the manager and external stakeholders will increase (Behn et al., 2008; Xu, 2010). Also, if information asymmetry between the manager and external stakeholders increases, resource distribution in the capital market is distorted by managers' incentives to increase internal transactions (Beaver, 1998).

From the viewpoint of auditors, the low earnings quality of a client should mean a high possibility for the manager to have prepared the financial statements with an opportunistic intention and this is a factor for increases in the client's inherent risk. In addition, it also means that the client's accounting system and internal accounting control system do not act effectively. As such, ineffective operation of accounting systems and internal accounting control systems cannot but act as a factor for increases in clients' control risks (Lee et al., 2012). Bedard and Johnstone (2004) report that auditors plans for increased effort and billing rates for clients with earnings manipulation risk. Heltzer and Shelton (2011) conducted a large-scale survey of auditors and found that on average, auditors perceive all types of large BTD to be related to an increase in audit risk.

In summary, large BTD increases clients' inherent risks and control risks to act as a factor to increase clients' audit risks, so auditors make efforts to lower the high audit risks of the clients. That is, auditors will make efforts to lower the audit risks by reinforcing audit procedures or expanding the range of proving procedures and consequently request additional compensation for the additional inputs of audit resources. Therefore, clients with large BTD are expected to incur long audit hours and high audit fees. In general, investors want independent auditors to remove intentional illegality, errors, or distortion contained in financial statements through accounting audits. In this regard, verifying whether auditors actually use this information in the stages of audit procedures considering BTD is considered as critical in proving the social functions of accounting audits.

In this study, the effects of individual firms' BTD on audit hours and audit fees were analyzed using the audit hour and audit fee data published on the business reports of firms listed on the Korea Stock Exchange (KSE) and the Korea Securities Dealers Automated Quotation (KOSDAQ) during the period 2005-2011. We predict that since auditors have the incentive and ability to consider BTD, audit hours and audit fees will increase when BTD are larger.

The empirical results of our study are as follows. First, BTD and audit hours show not statistically significant negative (-) association. Second, audit fees were shown to increase along with BTD. This can be interpreted as a result of requests for additional audit fees for increased audit risks due to individual firms' BTD. Third, the effect of corporate governance on the relationship between BTD and audit hours show a positive $(+)$ association, but the association was not statistically significant. From the viewpoint of governance, this can be regarded as meaning that better governance inputs additional audit hours that are necessary to improve governance. Fourth, the effect of corporate governance on the relationship between BTD and audit fees show statistically significant positive $(+)$ association. This means that firms with more excellent governance make more efforts for financial reporting to continuously maintain their reliability in the market.

This study contributes to the literature in several important aspects. First, we are meaningful in that it empirically demonstrated whether auditors properly reflect BTD on audit risks. The assumption of this study that when BTD are larger, auditors will try to reduce audit risks by expanding the range of proving procedures leading to increases in audit hours and audit fees is considered as a study design that reflects audit practices. Next, our study is additionally 
meaningful in that it analyzed the effects of corporate governance on the relationship between BTD and audit hours/audit fees using the total corporate governance (TCG) scores presented by the Korea Corporate Governance Service (KCGS). Finally, our findings empirically showed accounting audits' social proof function to reduce information risks.

The remainder of the paper is organized as follows. Section 2 reviews the related literature and develops the testable hypotheses. Section 3 discusses the research design. Section 4 presents the empirical results of the study. Finally, section 5 concludes the study.

\section{LITERATURE REVIEW AND HYPOTHESES DEVELOPMENT}

\subsection{Literature on Book-Tax Differences}

Book incomes are calculated according to the accounting standards on the accrual basis, while taxable incomes are calculated according to tax law provisions based on the settlement principle of claims and obligations. Therefore, unlike taxable incomes, book incomes are greatly affected by managers' opportunistic arbitrariness. When BTD are large, the managers' arbitrariness can be regarded to be large too. Previous studies have analyzed the effects of whether BTD and earnings management are identified and BTD on earnings persistence.

Phillips et al. (2003) documented that firms that report small positive earnings have a larger deferred tax expense, consistent with these firms managing book income upward to meet the target, but not reporting the additional income for tax purposes. Dhaliwal et al. (2004) presented a study result indicating that BTD are useful in identifying managers' opportunistic acts of earnings management. Hanlon (2005) reports that firms with large BTD have less persistent one-year-ahead earnings than firms with small BTD, suggesting that investors interpret book income far in excess of taxable income as a "red flag" about earnings quality. Blaylock et al. (2012) show that Hanlon's (2005) finding that large BTD are associated with lower earnings and accruals persistence is incremental to the effect of accruals on the persistence of earnings. As such, many previous studies have focused on managers' opportunistic arbitrariness and presented results indicating that larger BTD are associated with lower persistence of accounting earnings.

Decreases in the persistence of accounting earnings lead to reduction in information on future profits contained in profits for the term. Consequently, external stakeholders have relatively more inaccurate profit expectations based on information regarding profits for the term (Behn et al., 2008). Therefore, as BTD increased, the information asymmetry between the manager and diverse stakeholders regarding future profits increases (Choi et al., 2013).

Next, to review studies that verified information effects with BTD, Dhaliwal et al. (2008) presented significant positive $(+)$ relationships between the variability of BTD and implied costs of equity capitals to show that higher variability of BTD is accepted as more negative(-) information by the market. BTD also appear to be associated with credit risk. Ayers et al. (2010) and Crabtree and Maher (2009) find that higher BTD explain lower credit ratings.

To summarize, BTD are one of representative indicators of earnings quality and from the viewpoint of auditors, the fact that a client's earnings quality is low means a high possibility for the manager to have prepared the financial statements with opportunistic intentions. This behavior acts as a factor that increases a client's audit risk. Therefore, auditors will make additional efforts to reduce the audit risk and request audit fees corresponding to the efforts (Lee et al., 2012). Against this background, this study is intended to analyze the relationships between BTD and audit hours/audit fees.

\subsection{Literature on Audit Hours and Audit Fees}

As examined earlier, from the viewpoint of auditors, the low earnings quality of clients should be a factor that increases audit risks. Many prior studies presented results indicating that increases in audit risks lead to increases in audit hours and audit fees.

Ji and Moon (2006) examined whether an auditor's litigation risk affected audit hours and whether audit hours affect conservatism. They find that the increase in the litigation risk affects the increase in the audit hours and increased 
audit hours due to litigation risk affects the strengthening of conservatism. Gul and Goodwin (2010) find that the negative relation between short-term debt and audit fees is stronger for firms with low-quality credit ratings, consistent with auditors pricing lender monitoring.

Charles et al. (2010) examined a sample of 4,320 Big 4 client firm-years during the period 2000-2003 to examine the relation between audit fees and financial reporting risk (the risk of misleading or fraudulent reporting). They predict and find a statistically and economically significant positive association between audit fees and financial reporting risk. More importantly, they predict and find that the responsiveness of audit fees to financial reporting risk increased during the time period of their study.

Lee et al. (2012) show difference in relation between designation as an Unfaithful Disclosure Corporation (hereinafter UDC) and audit hours according to the exchange market. Specifically, audit hours are shown to increase for UDC designated firms listed on the Korea Stock Exchange (KSE) market, on the other hand, audit hours actually decrease for UDC designated firms listed on the Korea Securities Dealers Automated Quotation (KOSDAQ) market. The same results are found in the analysis when the number of designation times as UDC is set as the independent variable.

Auditors determine the level of detection risks based on clients' inherent risk and control risk. In addition, to lower clients' audit risk to acceptable levels, auditors set the nature, time, and range of proving procedures. If audit risks are high, auditors will increase audit hours inputted to reduce the audit risks and request audit fees corresponding to the audit hours. From the viewpoint of auditors, large BTD of clients can be interpreted as meaning that the manager prepared the financial statements with opportunistic intentions, and this fact will act as a factor that increases audit risks to auditors. This study is intended to analyze the effects of clients' BTD on audit risks.

\subsection{Literature on Corporate Governance}

Corporate governance is an area on which empirical studies are actively conducted not only in the field of accounting but also in the field of financial management. Prior studies related to corporate governance mostly examined the relationships between corporate governance and company values/business performance or the association between corporate governance and earnings quality. However, few studies examined the relationship between corporate governance and audit quality. Since an additional purpose of this study is to determine the effects of corporate governance on the relationships between BTD and audit hours/audit fees, prior literature will be reviewed centering on this relationship.

Cohen and Hanno (2000) examined how two important macro-level risk factors affect preplanning and planning judgment. Their finding could have significant implications for audit practice and research. As predicted, auditors are sensitive to corporate governance and management control philosophy in both preplanning and planning judgment. Carcello et al. (2002) show significant positive relations between audit fees and board independence, diligence, and expertise. The results are robust across numerous sensitivity tests, and they persist when measure of audit committee "quality" are included in the model. Abbott et al. (2003) examined the association between audit committee characteristics and audit fees. They predict and find that audit committees consisting solely of independent directors and having at least one financial expert are associated with higher audit fees.

Lee and Ryu (2011) examined the association between the corporate governance improvement and audit fees. They find a statistically significant positive relationship between independence and expertise of outside director and audit fees. Bedard and Johnstone (2004) analyzed the effects of earnings manipulation risks and corporate governance risks on audit hours and audit fees using questionnaire surveys. The results of the study indicated that when clients' earnings manipulation risks were higher, more audit efforts were inputted and audit fees per hour were higher. In particular, the researchers reported that such results were augmented when clients' corporate governance risks were higher.

The consensus of the literature is that, in general, when the board of directors and the audit committee are more independent, active, and professional, audit fees are higher and audit hours are longer. In addition, in cases where total corporate governance scores were used, researchers reported study results indicating that as total corporate 
governance scores increased, audit fees and audit hours also increased. However, questionnaire surveys presented results indicating that when corporate governance was better, audit hours and audit fees were lower, contrary to the above mentioned studies. Therefore, in this study, total corporate governance (TCG) scores which are data from the Korea Corporate Governance Service (KCGS), are additionally used to examine the interaction effects of corporate governance on the relationship between BTD and audit hours/audit fees.

\subsection{Hypotheses Development}

Managers adjust book incomes to obtain personal gains (Schipper, 1989). On the other hand, managers' opportunistic discretionary power is less involved in taxable incomes because taxable incomes are recognized when the time of reversion of profits and loss is fixed based on the settlement principle of claims and obligations. Therefore, BTD reflects considerable information in relation to managers' opportunistic discretion on accounting earnings or the quality of book incomes (Palepu et al., 2000; Phillips et al., 2003).

In particular, according to prior literature, empirical results have indicated that when BTD were higher, earnings quality was lower leading to decreases in the persistence of earnings were reported (Hanlon, 2005; Ko and Yoon, 2006). In previous studies, earnings quality has been used as a measure of information risks. In this case, information risks refer to the risk of financial statement users' damage due to wrong decision making in cases where decisions are made based on distorted accounting information. Financial statement users predict future cash flows based on firms' reported profits and make decisions using the relevant predicted information. Therefore, low earnings quality is highly likely to lead to poor decision making (Kwon and $\mathrm{Ki}, 2011$ ).

Since low earnings quality indicates information risks, if BTD increases, earnings quality will be deteriorated. Thus, information asymmetry between the manager and external stakeholders increases (Behn et al., 2008; Xu, 2010). If information asymmetry between the manager and external stakeholders is aggravated, resource distribution in the capital market will be distorted by managers' incentives to increase internal transactions (Beaver, 1998). Meanwhile, from the viewpoint of auditors, low earnings quality of a client should mean a high possibility for the manager to have prepared the financial statements with an opportunistic intention and this should act as a factor for increases in the client's inherent risk. In addition, it also means that the client's accounting system and internal accounting control system do not act effectively. As such, ineffective operation of accounting systems and internal accounting control systems cannot but act as a factor for increases in clients' control risks (Lee et al., 2012). Bedard and Johnstone (2004) report that auditors increase effort and billing rates for clients with earnings manipulation risk. Heltzer and Shelton (2011) conduct a large-scale survey of auditors and find that on average, auditors perceive all types of large BTD to be related to an increase in audit risk.

Therefore, large BTD will increase clients' inherent risks and control risks to act as a factor to increase clients' audit risks. Auditors will make efforts to lower the high audit risks of the clients. That is, auditors will make efforts to lower the audit risks by reinforcing audit procedures or expanding the range of proving procedures and consequently request additional compensation for the additional inputs of audit resources. According to the discussion above, we expect that the relationship between BTD and audit hours/audit fees can show a positive $(+)$ association. We thus propose the following two hypotheses:

$\mathbf{H}_{1 \mathbf{a}}$ : There is a positive association between large book-tax differences (BTD) and audit hours.

$\mathbf{H}_{1 \mathbf{b}}$ : There is a positive association between large book-tax differences (BTD) and audit fees.

There are two competing hypotheses effects of good corporate governance on audit fees and audit hours. One is the hypotheses that audit fees and audit hours increase when firms have excellent governance and the other one is a hypotheses that audit fees and audit hours decrease when auditors perceive audit risk (Park et al., 2013).

First, we consider the viewpoint of firms with excellent governance. This viewpoint regards audit services as a cost for achieving better governance and as part of continuous efforts to maintain reliability in the capital market. That is, firms equipped with excellent corporate governance may prefer high quality audits to satisfy the expectation of the capital market that wants high quality financial information and show additional efforts for audits increases in audit 
fees because these firms appoint high quality auditors. This viewpoint has been well demonstrated in the results of previous studies (Choi and Yang, 2008; Park et al., 2013).

In South Korea, firms with excellent corporate governance have good financial soundness so these firms may require more thorough audits to maintain their good assessment in the market requiring them to pay higher audit fees (Choi and Yang, 2008). In previous work, audit fees and audit hours have been used as proxies of audit quality because researchers regarded that clients want to receive audit services from those auditors who provide high quality audit services to enhance the reliability of their financial statements and auditors have the incentive to increase audit hours inputted and receive high audit fees as compensation for the long audit hours (Kwon and Kim, 2001; Park and Choi, 2009; Kwon and Ki, 2011). Therefore, prior studies regard that auditors that receive higher audit fees and input more audit hours as providing higher quality audit services.

Next, there is the viewpoint of auditors' audit risk that is contrary to the abovementioned viewpoint. The viewpoint regards information risks as leading to audit risks due to the information asymmetry in the imperfectly competitive market and if audit risks, audit hours and audit fees will also increase. Firms with excellent corporate governance may have systematic and effective internal control systems. If auditors utilize these systems when they establish audit plans, audit risks can be reduced to below the targeted level.

Therefore, the characteristics of corporate governance are closely related with audit risk (Park et al., 2013). As a study result from this viewpoint, Bedard and Johnstone (2004) showed a result indicating that when auditors make audit contracts and establish audit plans, more audit efforts are inputted and audit fees per hour increase when the risk of clients' earnings manipulation is higher. In particular, the researchers reported that this result is further intensified when clients' corporate governance risks are high. When seen from this viewpoint of auditors' audit risks, when corporate governance is more excellent, auditors can achieve the targeted audit risk even with relatively less efforts because internal control systems are systematic and financial reporting systems are well established in such cases (Choi and Yang, 2008; Park et al., 2013). Eventually, if this viewpoint is taken, audit hours inputted and audit fees can be reduced.

According to the discussion above, the effects of corporate governance on the relationship between BTD and audit hours/audit fees can show either positive (+) association or negative (-) association. Based on this fact, we thus propose the following two hypotheses:

$\mathbf{H}_{2 \mathbf{a}}$ : The effects of corporate governance on the relationship between book-tax differences (BTD) and audit hours are not different.

$\mathbf{H}_{2 \mathbf{b}}$ : The effects of corporate governance on the relationship between book-tax differences (BTD) and audit fees are not different.

\section{RESEARCH DESIGN}

\subsection{Research Models}

This study investigates whether auditors input additional audit hours according to the sizes of BTD and request additional audit fees for the additional audit hours. In addition, the interaction effects of corporate governance on the relationships between BTD and audit hours/audit fees be examined using the total corporate governance (TCG) scores which are data from the Korea Corporate Governance Service (KCGS). We use the following regression models to gain insight into the effects of BTD on audit hours/audit fees.

$$
\begin{aligned}
& L_{n A H_{t}}=\beta_{0}+\beta_{1} B T D_{t}+\beta_{2} B I G 4_{t}+\beta_{3} F_{I R S T_{t}}+\beta_{4} O P N_{t}+\beta_{5} S_{I Z E_{t}}+\beta_{6} L E V_{t}+\beta_{7} L I G_{t}+\beta_{8} G R W_{t}+\beta_{9} \text { CON }_{t}+ \\
& \beta_{10} I N V R E C_{t}+\beta_{11} R O A_{t}+\beta_{12} L_{O S S_{t}}+\beta_{13} O W N_{t}+\beta_{14} F O R N_{t}+\sum I N D+\sum Y D+ \\
& \varepsilon_{t} \\
& L n A F_{t}=\beta_{0}+\beta_{1} B T D_{t}+\beta_{2} B_{I G 4_{t}}+\beta_{3} \text { FIRST }_{t}+\beta_{4} O P N_{t-1}+\beta_{5} \operatorname{SIZE}_{t-1}+\beta_{6} L E V_{t-1}+\beta_{7} L I G_{t-1}+\beta_{8} G R W_{t-1}+ \\
& \beta_{9} \operatorname{CON}_{t}+\beta_{10} I N V R E C_{t-1}+\beta_{11} R O A_{t-1}+\beta_{12} L_{O S S_{t-1}}+\beta_{13} O W N_{t}+\beta_{14} F O R N_{t}+\sum I N D+\sum Y D+\varepsilon_{t}
\end{aligned}
$$




$$
\begin{aligned}
& \operatorname{LnAH}_{t}=\beta_{0}+\beta_{1} B T D_{t}+\beta_{2} G O V_{t}+\beta_{3} B T D_{t} \times G O V_{t}+\beta_{4} B I G 4_{t}+\beta_{5} \text { FIRST }_{t}+\beta_{6} O P N_{t}+\beta_{7} \operatorname{SIZE}_{t}+\beta_{8} L E V_{t} \\
& +\beta_{9} L I G_{t}+\beta_{10} G R W_{t}+\beta_{11} \operatorname{CON}_{t}+\beta_{12} I N V R E C_{t}+\beta_{13} R O A_{t}+\beta_{14} L_{O S S} \\
& +\beta_{15} O W N_{t}+\beta_{16} F O R N_{t}+\sum I N D+\sum Y D+\varepsilon_{t} \\
& L n A F_{t}=\beta_{0}+\beta_{1} B T D_{t}+\beta_{2} G O V_{t}+\beta_{3} B T D_{t} \times G O V_{t}+\beta_{4} B I G 4_{t}+\beta_{5} F_{R S S T}+\beta_{6} O P N_{t-1}+\beta_{7} S_{I Z E_{t-1}} \\
& +\beta_{8} L E V_{t-1}+\beta_{9} L I G_{t-1}+\beta_{10} G R W_{t-1}+\beta_{11} C_{C O N}+\beta_{12} I N V R E C_{t-1}+\beta_{13} R O A_{t-1} \\
& +\beta_{14} L O S S_{t-1}+\beta_{15} O W N_{t}+\beta_{16} F O R N_{t}+\sum I N D+\sum Y D+\varepsilon_{t}
\end{aligned}
$$

In the case of South Korea, audit fees are determined in the stage of making audit contracts based on the audit client's financial data for the immediately previous year. Therefore, audit fees cannot be easily adjusted in the process of conducting audits. Due to this practical phenomenon, there are differences in the time points of measurement of dependent variables and independent variables between model (1) and (3) in which a dependent variable is audit hours $(\operatorname{LnAH})$ and model $(2)$ and (4) in which a dependent variable is audit fees $(\operatorname{LnAF})$. However, in the case of the size of auditors (BIG4) and whether the audit is the initial audit (FIRST) related to auditors' characteristics, there are no differences in time points of measurement between dependent variables and independent variables in model (2) and (4). Because of the characteristics of variables, year t was appropriate for the size of the auditor $(B I G 4)$, the initial audit $(F I R S T)$, the complexity of business $(C O N)$, the largest shareholders ownership $(O W N)$, and foreign ownership $(F O R N)$ as with audit hours $(\operatorname{LnAH})$. Therefore, these variables were measured in year $\mathrm{t}$ (Kwon and $\mathrm{Ki}, 2011$ ).

Those variables that had been known to affect audit hours, and audit fees through prior literature were set as control variables. If the size of the auditor $(B I G 4)$ is large, the auditor will increase audit hours inputted to maintain the reputation of the auditor (Francis 1984; Palmrose 1989; Lee et al. 2012). Therefore, the size of the auditor (BIG4) is expected to have a positive $(+)$ association for each of audit hours (LnAH) and audit fees (LnAF). Prior studies suggest that initial audit fees are discounted due to the keen competition under the free appointment acceptance system. Therefore, the initial audit $(F I R S T)$ was added as a control variable. Not unqualified opinion $(O P N)$ is expected to have a positive $(+)$ association with audit hours $(\operatorname{LnAH})$ and audit fees $(\operatorname{LnAF})$ because of high audit risks (Palmrose 1986; Simunic 1980; Kwon and Ki 2011; Lee et al. 2012). The firm size (SIZE) and complexity of business $(C O N)$ of audit clients become important factors that determine audit inputs. (Palmrose 1989; Francis 1984; Lee et al. 2012). Therefore, the firm sizes (SIZE) and complexity of business (CON) that represents whether consolidated financial statements are reported were added to the model as control variables.

The debt ratio $(L E V)$ is related to long-term financial safety and the current ratio $(L I Q)$ is related to short-term financial safety (Kwon and Ki 2011; Lee et al. 2012). The debt ratio (LEV) is expected to have a positive (+) relationship with audit hours $(L n A H)$ and audit fees $(L n A F)$. The current ratio $(L I Q)$ is expected to have a negative () relationship with audit hours $(L n A H)$ and audit fees $(L n A F)$. In addition, a variable that represents one-year growth rate in sales $(G R W)$ was added to the control variables. Prior studies suggest that firms with high growth rate in sales may have high possibility of earnings management (Lee et al. 2012). When audits are being conducted, audit hours and audit fees are expected to increase as inventory assets and account receivables increases due to inquiry procedures and diligence work (Choi and Ju 1998). To control these effects, the ratio of inventory (INVREC) and account receivables to total assets was added to control variables. The possibility of earnings management by audit clients will increase when the return on assets $(R O A)$ is low or loss (LOSS) occurred. As a result, increases in audit risks (Francis 1984; Blankley et al. 2012; Lee et al. 2012).

With regard to corporate governance, the largest shareholders ownership $(O W N)$ and foreign ownership (FORN) were added to control variable. With regard to the effects of the largest shareholders ownership on firms, conflicting study results have been reported. A related theory is the hypotheses of interest congruence indicating that the large shareholders can faithfully supervise manager. A second theory is the hypotheses of interest infringement expecting that the large shareholders will pursue personal gains to infringe minority shareholders' interest rather than supervising manager (Kim and Byun 2010). In addition, because expectations of the reliability of accounting 
information increase when foreign shareholders share ratios are high, clients come to prefer conservative accounting treatment (Kim and Bae 2006). Finally, a vector of indicator variables is included to control for industry and year fixed effects.

\subsection{Sample Selection}

In this study, our sample consisted of firms listed on the Korea Composite Stock Price Index (KOSPI) during the period 2005-2011. We obtained financial data from TS 2000 database of Korea Listed Firms Association, which provides the financial statements of all listed firms. For comparability, we deleted firms with non-December fiscal year-ends and all firms in which total liabilities were larger than the total assets. This screening procedure yielded a total of 3,824 firm-year observations. Table 1 shows the sample selection criteria and the number of excluded firms to arrive at our final sample.

Table 1. Sample Selection

\begin{tabular}{l|c}
\hline \multicolumn{1}{c}{ Sample Selection Criteria } & N \\
\hline $\begin{array}{l}\text { Firm-year observations with December fiscal year-ends and listed on the KOSPI during the } \\
\text { period 2005-2011 database of the Korea Listed Firms Association }\end{array}$ & 4,920 \\
\hline $\begin{array}{l}\text { (Less) Firm-year observations without the audit fees and audit hours data from the TS } 2000 \\
\text { database }\end{array}$ & $(404)$ \\
\hline $\begin{array}{l}\text { (Less) Firm-year observations without the corporate governance scores from the Korea } \\
\text { Corporate Governance Service }\end{array}$ & $(324)$ \\
\hline $\begin{array}{l}\text { (Less) Firm-year observations without the book-tax difference data } \\
\text { (Less) Firm-year observations for which financial data are not available }\end{array}$ & $(130)$ \\
\hline Total number of firm-year observations in the final sample & $(238)$ \\
\hline
\end{tabular}

\section{EMPRICAL RESULTS}

\subsection{Descriptive Statistics and Correlation Analysis}

Table 2 shows the descriptive statistics of the major variables. The mean (median) of audit hours (LnAH) was 6.918(6.816), and the mean (median) of audit fees $(L n A F)$ was $11.397(11.238)$. The mean and median of BTD, the variable of interest were 0.040 and 0.016 , respectively. In the case of $B T D$, the mean and median showed a difference indicating that some firms have large $B T D$. The mean of $G O V$, which is a dummy variable representing corporate governance, is 0.507 , and this means that the samples of total corporate governance scores are appropriately distributed on the basis of the mean. As for the variables representing auditor characteristics, the mean of BIG4 was shown to be $71.1 \%$, and the mean of FIRST was shown to be $18.5 \%$. The mean of $O P N$ was low at $0.1 \%$.

As for the variables representing the corporate characteristics, the mean of SIZE was 19.877 and the mean of $L E V$ was $56.1 \%$. The mean of $L I Q$ was 1.719 , and the mean of $G R W$ was $11.3 \%$. The mean of $C O N$ was $69.4 \%$, and the mean of INVREC was $34.7 \%$. As for profitability, the mean of ROA was $3.1 \%$, and the mean of $L O S S$ was $19.9 \%$. As for ownership structures, the mean of $O W N$ was $41.7 \%$. This shows that the share ratios of major shareholders including affiliated persons are high at approximately 40\% indicating the governance (Park et al. 2013). The mean of FORN was shown to be $11.7 \%$. The mean and the median show a big difference and this seems to be the result of foreign investors' intensive investments in several preferred firms (Park et al. 2013). 
Table 2. Descriptive Statistics $(\mathrm{N}=3,824)$

\begin{tabular}{|c|c|c|c|c|c|c|c|}
\hline Variables & Mean & Std. & Min & $25 \%$ & Median & $75 \%$ & Max \\
\hline LnAH & 6.918 & 0.956 & 1.609 & 6.394 & 6.816 & 7.336 & 10.783 \\
\hline $\operatorname{Ln} A F$ & 11.397 & 0.839 & 7.496 & 10.877 & 11.238 & 11.775 & 15.150 \\
\hline$B T D$ & 0.040 & 0.117 & 0.000 & 0.006 & 0.016 & 0.041 & 5.180 \\
\hline$G O V$ & 0.507 & 0.500 & 0.000 & 0.000 & 1.000 & 1.000 & 1.000 \\
\hline$B T D^{*} G O V$ & 0.015 & 0.037 & 0.000 & 0.000 & 0.000 & 0.015 & 0.954 \\
\hline$B I G 4$ & 0.711 & 0.454 & 0.000 & 0.000 & 1.000 & 1.000 & 1.000 \\
\hline FIRST & 0.185 & 0.388 & 0.000 & 0.000 & 0.000 & 0.000 & 1.000 \\
\hline$O P N$ & 0.001 & 0.032 & 0.000 & 0.000 & 0.000 & 0.000 & 1.000 \\
\hline SIZE & 19.877 & 1.649 & 15.804 & 18.673 & 19.572 & 20.759 & 25.623 \\
\hline$L E V$ & 0.561 & 0.296 & 0.012 & 0.362 & 0.547 & 0.706 & 4.436 \\
\hline$L I Q$ & 1.719 & 1.565 & 0.042 & 0.963 & 1.311 & 1.908 & 40.785 \\
\hline$G R W$ & 0.113 & 0.578 & -0.999 & -0.015 & 0.059 & 0.167 & 15.556 \\
\hline$C O N$ & 0.694 & 0.461 & 0.000 & 0.000 & 1.000 & 1.000 & 1.000 \\
\hline INVREC & 0.347 & 0.189 & 0.001 & 0.219 & 0.330 & 0.450 & 2.489 \\
\hline$R O A$ & 0.031 & 0.133 & -4.823 & 0.006 & 0.036 & 0.072 & 1.197 \\
\hline LOSS & 0.199 & 0.399 & 0.000 & 0.000 & 0.000 & 0.000 & 1.000 \\
\hline$O W N$ & 0.417 & 0.164 & 0.023 & 0.302 & 0.414 & 0.518 & 0.935 \\
\hline FORN & 0.117 & 0.159 & 0.000 & 0.006 & 0.045 & 0.171 & 0.876 \\
\hline
\end{tabular}

Note: This table reports the descriptive statistics for the variables used in the sample (3,824 firm-year observations) including the listed firms on the Korea Composite Stock Price Index (KOSPI) during the period 2005-2011.

Definitions of the variables:

$L n A H_{\mathrm{t}}$ : the natural log of audit hours for firm i in year $\mathrm{t}$;

$L n A F_{\mathrm{t}}$ : the natural $\log$ of audit fees for firm i in year $\mathrm{t}$;

$B T D_{\mathrm{t}}$ : the absolute value of the spread between pretax book income and taxable income for firm $\mathrm{i}$ in year $\mathrm{t}$;

$G O V_{\mathrm{t}}$ : the total corporate governance (TCG) scores which are data from the Korea Corporate Governance Service (KCGS) for firm $i$ in year $t$;

$B I G 4_{\mathrm{t}}: 1$ if the firm audited by a Big 4 auditor, and 0 otherwise for firm $\mathrm{i}$ in year $\mathrm{t}$;

FIRST $_{\mathrm{t}}: 1$ if the firm is the initial audit firm, and 0 otherwise for firm $\mathrm{i}$ in year $\mathrm{t}$;

$O P N_{\mathrm{t}-1(\mathrm{t})}: 1$ if an audit opinion is not unqualified opinion, and 0 otherwise for firm $i$ in year $t-1(t)$;

$S I Z E_{\mathrm{t}-1(\mathrm{t})}:$ the natural $\log$ of lagged total assets for firm $\mathrm{i}$ in year $\mathrm{t}-1(\mathrm{t})$;

$L E V_{\mathrm{t}-1(\mathrm{t})}:$ total debt divided by total assets for firm $\mathrm{i}$ in year $\mathrm{t}-1(\mathrm{t})$;

$L I Q_{\mathrm{t}-1(\mathrm{t})}:$ current assets divided by current liabilities for firm $\mathrm{i}$ in year $\mathrm{t}-1(\mathrm{t})$;

$G R W_{\mathrm{t}-1(\mathrm{t})}$ : one-year growth rate in sales for firm $\mathrm{i}$ in year $\mathrm{t}-1(\mathrm{t})$;

$C O N_{\mathrm{t}}: 1$ if the firm reported consolidated financial statements, and 0 otherwise for firm $\mathrm{i}$ in year $\mathrm{t}-1(\mathrm{t})$;

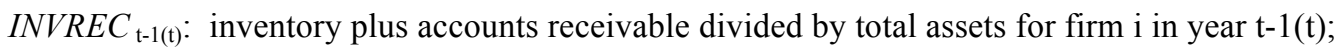

$R O A_{\mathrm{t}-1(\mathrm{t})}:$ pretax income divided by total assets for firm $\mathrm{i}$ in year $\mathrm{t}-1(\mathrm{t})$;

$\operatorname{LOSS}_{\mathrm{t}-1(\mathrm{t})}: 1$ if the firm reported negative net income, and 0 otherwise for firm $\mathrm{i}$ in year $\mathrm{t}-1(\mathrm{t})$; 
$O W N_{\mathrm{t}}$ : the largest shareholders ownership for firm i in year t;

$F O R N_{\mathrm{t}}$ : the foreign ownership for firm $\mathrm{i}$ in year $\mathrm{t}$;

Table 3 provides the Pearson correlation coefficient for the various combination of control and test variables. The correlation coefficient between audit hours $(L n A H)$ and audit fees $(L n A F)$ is shown to be 0.844 which is a significant positive $(+)$ value. Audit hours $(L n A H)$ and audit fees $(L n A F)$ intended to verify hypotheses 1 and 2 of this study show significant negative (-) correlation with $B T D$. This means that when $B T D$ are larger, less audit hours are inputted and smaller amounts of audit fees are requested. Contrary to the predictions by hypotheses 1 and 2, negative correlation coefficients appeared instead of positive correlation coefficients. Since this result is not a result of a multi-variate regression analysis, the correlations between audit hours $(\operatorname{LnAH})$ /audit fees $(\operatorname{LnAF})$ and $B T D$ will be examined considering all control variables.

Audit hours $(L n A H)$ and audit fees $(L n A F)$ show significant positive $(+)$ correlations with $G O V$ that means corporate governance. This result support the viewpoint of governance in relation to hypotheses 3 and 4 . This means that firms with better governance input more audit hours to enhance audit quality and audit fees are requested in exchange of additional efforts. Audit hours $(L n A H)$ and audit fees $(L n A F)$ show significant positive $(+)$ correlations with BIG4. This means that larger auditors are associated with more audit hours $(L n A H)$ and higher audit fees $(L n A F)$. Audit hours $(L n A H)$ and audit fees $(L n A F)$ show significant negative (-) correlations with FIRST. This can be understood as a result of discounts of compensations for initial audits. Audit hours (LnAH) and audit fees (LnAF) show significant positive $(+)$ correlations with SIZE. This can be understood as meaning that the size of clients plays a very important role as a determinant of audit hours $(\operatorname{LnAH})$ and audit fees $(\operatorname{LnAF})$ and has significant positive $(+)$ correlations with audit hours $(L n A H)$ and audit fees $(L n A F)$. Audit hours $(L n A H)$ show significant positive $(+)$ correlations with $L E V, G R W, C O N, R O A$, and FORN and significant negative (-) correlations with LIQ, INVREC, $L O S S$, and $O W N$. Audit fees $(L n A F)$ also show similar results.

Table 3. Correlations among the Variables

\begin{tabular}{|c|c|c|c|c|c|c|c|c|}
\hline & LnAH & LnAF & BTD & GOV & BTD*GOV & BIG4 & FIRST & OPN \\
\hline $\operatorname{LnAF}$ & 0.8441 & & & & & & & \\
\hline$B T D$ & -0.1068 & -0.0638 & & & & & & \\
\hline$G O V$ & 0.3529 & 0.3929 & -0.0927 & & & & & \\
\hline$B T D * G O V$ & 0.1442 & 0.1595 & 0.2325 & 0.3931 & & & & \\
\hline$B I G 4$ & 0.4177 & 0.3759 & -0.0607 & 0.2244 & 0.0773 & & & \\
\hline FIRST & -0.0422 & -0.0812 & 0.0167 & -0.0271 & -0.0027 & -0.0356 & & \\
\hline$O P N$ & 0.0150 & 0.0118 & 0.0211 & -0.0166 & 0.0512 & 0.0028 & -0.0154 & \\
\hline SIZE & 0.7088 & 0.7851 & -0.1136 & 0.4362 & 0.1811 & 0.3745 & -0.0619 & 0.0126 \\
\hline$L E V$ & 0.1514 & 0.2027 & 0.1555 & -0.0157 & 0.0670 & 0.0482 & 0.0021 & -0.0030 \\
\hline$L I Q$ & -0.1576 & -0.1895 & -0.0314 & 0.0277 & -0.0251 & -0.1099 & 0.0086 & -0.0112 \\
\hline$G R W$ & 0.0105 & 0.0130 & 0.1698 & -0.0195 & 0.0395 & -0.0040 & -0.0106 & -0.0199 \\
\hline$C O N$ & 0.2948 & 0.3241 & -0.0291 & 0.0937 & 0.0390 & 0.1480 & -0.0327 & 0.0039 \\
\hline INVREC & -0.1539 & -0.1551 & 0.0588 & -0.0688 & -0.0232 & -0.1085 & 0.0091 & -0.0299 \\
\hline$R O A$ & 0.0931 & 0.0597 & -0.6125 & 0.1173 & -0.0151 & 0.0544 & -0.0075 & -0.0349 \\
\hline LOSS & -0.0554 & -0.0714 & 0.2043 & -0.1776 & 0.0357 & -0.0548 & 0.0139 & 0.0649 \\
\hline$O W N$ & -0.1799 & -0.2177 & -0.0791 & -0.1473 & -0.0771 & -0.0009 & 0.0130 & -0.0316 \\
\hline FORN & 0.3393 & 0.3895 & -0.0585 & 0.2799 & 0.1163 & 0.2539 & -0.0492 & 0.0196 \\
\hline
\end{tabular}


(Table 3 continued)

\begin{tabular}{|c|c|c|c|c|c|c|c|c|c|}
\hline & SIZE & LEV & LIQ & GRW & $\mathrm{CON}$ & INVREC & ROA & LOSS & OWN \\
\hline \multicolumn{10}{|l|}{ LnAF } \\
\hline \multirow{2}{*}{\multicolumn{10}{|c|}{$B T D$}} \\
\hline & & & & & & & & & \\
\hline \multicolumn{10}{|l|}{$B T D^{*} G O V$} \\
\hline \multicolumn{10}{|l|}{ BIG4 } \\
\hline \multirow{2}{*}{\multicolumn{10}{|c|}{$\begin{array}{l}\text { FIRST } \\
\text { OPN }\end{array}$}} \\
\hline & & & & & & & & & \\
\hline \multicolumn{10}{|l|}{ SIZE } \\
\hline LEV & 0.1555 & & & & & & & & \\
\hline$L I Q$ & -0.2005 & -0.4391 & & & & & & & \\
\hline$G R W$ & -0.0174 & 0.1677 & -0.0320 & & & & & & \\
\hline CON & 0.4602 & 0.1650 & -0.1676 & -0.0093 & & & & & \\
\hline INVREC & -0.2919 & 0.3947 & 0.0025 & 0.1460 & -0.1110 & & & & \\
\hline$R O A$ & 0.0909 & -0.1695 & 0.0979 & 0.0908 & 0.0087 & 0.0532 & & & \\
\hline LOSS & -0.1078 & 0.1229 & -0.0882 & -0.0624 & -0.0490 & -0.0824 & -0.4481 & & \\
\hline$O W N$ & -0.1140 & -0.0465 & 0.0018 & 0.0093 & -0.0626 & -0.0026 & 0.0499 & -0.0062 & \\
\hline FORN & 0.4436 & -0.0984 & 0.0633 & -0.0197 & 0.1941 & -0.1208 & 0.1518 & -0.0984 & -0.1049 \\
\hline
\end{tabular}

Note: This table reports pairwise Pearson correlations the diagonal for variables. Coefficients shown in bold are significant at $\mathrm{p}<0.05$ (two-tailed test). See Table 2 for all variable definitions.

\subsection{Multivariate Results}

Table 4 provides the results of estimating Model (1) to test our hypotheses 1. Although BTD and audit hours (LnAH) showed negative (-) association, the association was not statistically significant. The $\mathrm{F}$ value of the audit hours $(L n A H)$ determination model was shown to be statistically significant indicating that the setting of the study model was appropriate. The explanatory power $\left(\mathrm{adj} . R^{2}\right)$ of the model was shown as 58.85 .

The control variables $B I G 4$, SIZE, LEV, INVREC, ROA, and LOSS show significant positive (+) relationships with audit hours $(L n A H)$ while the control variables $C O N$ and OWN show significant negative (-) relationships with audit hours $(\operatorname{Ln} A H)$. That is, this means that firms audited by Big 4 accounting firms, larger firms, and firms with higher debt ratios inputted more audit hours $(L n A H)$. In addition, firms with higher ratios of inventory assets and accounts receivables, firms with larger losses, and firms with higher return on total assets inputted more audit hours $(\operatorname{Ln} A H)$. In the case of $B I G 4$, these results mean that larger auditors input more audit hours to maintain their reputation. Firms with higher major shareholders' share ratios were shown to input less audit hours. These results were generally consistent the results of previous studies that analyzed audit hour determination models (Lee et al. 2012; Kwon and Ki 2011). 
Table 4. The Effect of Book-Tax Differences on Audit Hours

$$
\begin{aligned}
L_{n A H_{t}=} & \beta_{0}+\beta_{1} B T D_{t}+\beta_{2} \text { BIG }_{t}+\beta_{3} \text { IIRST }_{t}+\beta_{4} O P N_{t}+\beta_{5} \text { SIZE }_{t}+\beta_{6} L E V_{t}+\beta_{7} L I G_{t}+\beta_{8} G R W_{t}+\beta_{9} \text { CON }_{t}+\beta_{10} I N V R E C_{t}+ \\
& \beta_{11} R O A_{t}+\beta_{12} \operatorname{LOSS}_{t}+\beta_{13} O W N_{t}+\beta_{14} F O R N_{t}+\sum I N D+\sum Y D+\varepsilon_{t}
\end{aligned}
$$

\begin{tabular}{|c|c|c|c|c|c|}
\hline Variables & Expected Sign & Coefficient & Standard error & t-statistic & p-value \\
\hline NTERCEPT & & -1.244 & 0.180 & -6.890 & $<.0001$ \\
\hline$B T D$ & $+/-$ & -0.141 & 0.127 & -1.100 & 0.270 \\
\hline$B I G 4$ & + & 0.372 & 0.025 & $15.180^{* * *}$ & $<.0001$ \\
\hline FIRST & + & 0.023 & 0.027 & 0.870 & 0.384 \\
\hline$O P N$ & + & 0.250 & 0.359 & 0.700 & 0.486 \\
\hline SIZE & + & 0.394 & 0.009 & $43.350^{* * *}$ & $<.0001$ \\
\hline$L E V$ & + & 0.108 & 0.048 & $2.240^{* *}$ & 0.025 \\
\hline$L I Q$ & - & -0.008 & 0.008 & -1.110 & 0.269 \\
\hline$G R W$ & + & 0.011 & 0.019 & 0.560 & 0.574 \\
\hline$C O N$ & + & -0.112 & 0.026 & -4.310 & $<.0001$ \\
\hline INVREC & + & 0.221 & 0.072 & $3.060^{* * *}$ & 0.002 \\
\hline$R O A$ & + & 0.413 & 0.135 & $3.070^{* * *}$ & 0.002 \\
\hline LOSS & + & 0.077 & 0.030 & $2.560^{* *}$ & 0.011 \\
\hline$O W N$ & - & -0.424 & 0.066 & $-6.430^{* * *}$ & $<.0001$ \\
\hline FORN & + & -0.042 & 0.078 & -0.540 & 0.588 \\
\hline Year Dummy & & \multicolumn{4}{|c|}{ Included } \\
\hline Industry Dummy & & \multicolumn{4}{|c|}{ Included } \\
\hline$F-V A L U E$ & & \multicolumn{4}{|c|}{$151.87^{* * *}$} \\
\hline $\operatorname{Adj} . R^{2}$ & & \multicolumn{4}{|c|}{0.5885} \\
\hline
\end{tabular}

Note: This table provides the regression estimates of the model (1) that examines the effect of book-tax differences on audit hours. The model includes year and industry fixed effects based on the two-digit Korean Standard Industry Codes. T-statistics are corrected for heteroskedasticity. ***, **, and $*$ denote statistical significance at $1 \%, 5 \%$, and $10 \%$ levels respectively, based on two-tailed test. The sample consists of 3,824 firm-year observations between 2005 and 2011. See Table 2 for all variable definitions.

Table 5 provides the results of estimating Model (2) to test our hypotheses 2. BTD and audit fees (LnAF) were shown to have significant positive $(+)$ association. This can be understood that additional audit fees are requested for individual firms' increased audit risks due BTD. The $\mathrm{F}$ value of the audit fees (LnAF) determination model was shown to be statistically significant indicating that the setting of the study model was appropriate. The explanatory power $\left(\right.$ adj. $\left.R^{2}\right)$ of the model was shown as 68.46 .

The control variables are generally shown to have significant relationships with audit fees $(L n A F)$. Concretely, the control variables BIG4, SIZE, LEV, INVREC, ROA, LOSS, and FORN show significant positive (+) relationships with audit fees $(L n A F)$ and the control variables FIRST, LIQ, CON, and OWN show significant negative (-) relationships with audit fees $(L n A F)$. That is, this means that firms audited by Big 4 accounting firms, larger firms, and firms with higher debt ratios required higher audit fees $(L n A F)$. In addition, firms with higher ratios of inventory assets and accounts receivables, firms with larger losses, and firms with higher return on total assets required higher audit fees $(L n A F)$. Firms that were receiving the initial audit, firms with high current ratios, firms that were preparing consolidated financial statements, and firms with high major shareholders' share ratios were shown to have been requested for low audit fees $(L n A F)$. These results were generally consistent the results of previous studies that analyzed audit hour determination models (Lee et al. 2012; Kwon and Ki 2011). 
Table 5. The Effect of Book-Tax Differences on Audit Fees

$$
\begin{array}{r}
\operatorname{LnAF}_{t}=\quad \begin{array}{r}
\beta_{0}+\beta_{1} \text { BTD }_{t}+\beta_{2} \text { BIG }_{t}+\beta_{3} \text { FIRST }_{t}+\beta_{4} O P N_{t-1}+\beta_{5} \text { SIZE }_{t-1}+\beta_{6} L E V_{t-1}+\beta_{7} L I G_{t-1}+\beta_{8} G R W_{t-1}+\beta_{9} C_{\text {OON }} \\
+
\end{array} \\
+\beta_{10} I N V R E C_{t-1}+\beta_{11} R O A_{t-1}+\beta_{12} L O S S_{t-1}+\beta_{13} O W N_{t}+\beta_{14} F O R N_{t}+\sum I N D+\sum Y D+\varepsilon_{t}
\end{array}
$$

\begin{tabular}{|c|c|c|c|c|c|}
\hline Variables & Expected Sign & Coefficient & Standard error & t-statistic & p-value \\
\hline NTERCEPT & & 3.557 & 0.138 & $25.720^{* * *}$ & $<.0001$ \\
\hline$B I G 4$ & + & 0.174 & 0.019 & $9.210^{* * *}$ & $<.0001$ \\
\hline FIRST & - & -0.065 & 0.020 & $-3.160^{* * *}$ & 0.002 \\
\hline$O P N$ & + & -0.046 & 0.275 & -0.170 & 0.866 \\
\hline SIZE & + & 0.387 & 0.007 & $55.520^{* * *}$ & $<.0001$ \\
\hline$L E V$ & + & 0.218 & 0.037 & $5.920^{* * *}$ & $<.0001$ \\
\hline$L I Q$ & - & -0.014 & 0.006 & $-2.380^{* *}$ & 0.017 \\
\hline$G R W$ & + & 0.018 & 0.014 & 1.300 & 0.193 \\
\hline$C O N$ & + & -0.073 & 0.020 & $-3.620^{* * *}$ & 0.000 \\
\hline INVREC & + & 0.192 & 0.054 & $3.560^{* * *}$ & 0.000 \\
\hline$R O A$ & + & 0.185 & 0.099 & $1.870^{*}$ & 0.062 \\
\hline LOSS & + & -0.015 & 0.023 & -0.650 & 0.515 \\
\hline$O W N$ & - & -0.426 & 0.051 & $-8.380^{* * *}$ & $<.0001$ \\
\hline FORN & + & 0.181 & 0.060 & $3.010^{* * *}$ & 0.003 \\
\hline Year Dummy & & \multicolumn{4}{|c|}{ Included } \\
\hline Industry Dummy & & \multicolumn{4}{|c|}{ Included } \\
\hline$F-V A L U E$ & & \multicolumn{4}{|c|}{$231.07^{* * *}$} \\
\hline Adj. $R^{2}$ & & \multicolumn{4}{|c|}{0.6846} \\
\hline
\end{tabular}

Note: This table provides the regression estimates of the model (2) that examines the effect of book-tax differences on audit fees. The model includes year and industry fixed effects based on the two-digit Korean Standard Industry Codes. T-statistics are corrected for heteroskedasticity. ***, **, and * denote statistical significance at $1 \%, 5 \%$, and $10 \%$ levels respectively, based on two-tailed test. The sample consists of 3,824 firm-year observations between 2005 and 2011. See Table 2 for all variable definitions.

Table 6 provides the results of estimating Model (3) to test our hypotheses 3 . The interaction effects of corporate governance on the relationships between BTD and audit hours $(\operatorname{LnAH})$ showed a positive $(+)$ association, but the association was not statistically significant. This result means that corporate governance plays the role of increasing audit hours $(L n A H)$ in the relationship between individual firms' $B T D$ and audit hours $(\operatorname{LnAH})$. That is, in the case of domestic listed firms, the effects of corporate governance on the relationship between $B T D$ and audit hours (LnAH) can be regarded as supporting the viewpoint of governance rather than the viewpoint of auditors' audit risks. Therefore, firms equipped with excellent governance can be regarded as demanding differentiated audits to construct more desirable governance accordingly increasing audit fees of auditors with high audit quality in the audit market. Auditors can be regarded as increasing the input of audit hours ( $L n A H)$, which is an economic resource to satisfy the demand of firms that want excellent governance for differentiated audits. The remaining control variables are generally shown to have significant relationships with audit hours $(\operatorname{Ln} A H)$. Concretely, the control variables $B I G 4$, $S I Z E, L E V$, INVREC, ROA, and LOSS show significant positive (+) relationships with audit hours (LnAH) and control variables $L I Q, C O N$, and $O W N$ show significant negative (-) relationships with audit hours $(\operatorname{Ln} A H)$. 
Table 6. The Effect of Corporate Governance on the Association between Book-Tax Differences and Audit Hours

$\begin{array}{ll}\mathrm{LnAH}_{\mathrm{t}}= & \beta_{0}+\beta_{1} \mathrm{BTD}_{\mathrm{t}}+\beta_{2} \mathrm{GOV}_{\mathrm{t}}+\beta_{3} \mathrm{BTD}_{\mathrm{t}} \times \mathrm{GOV}_{\mathrm{t}}+\beta_{4} \mathrm{BIG}_{\mathrm{t}}+\beta_{5} \mathrm{FIRST}_{\mathrm{t}}+\beta_{6} \mathrm{OPN}_{\mathrm{t}}+\beta_{7} \mathrm{SIZE}_{\mathrm{t}}+\beta_{8} \mathrm{LEV}_{\mathrm{t}}+\beta_{9} \mathrm{LIG}_{\mathrm{t}}+\beta_{10} \mathrm{GRW}_{\mathrm{t}}+ \\ & \beta_{11} \mathrm{CON}_{\mathrm{t}}+\beta_{12} \mathrm{INVREC}_{\mathrm{t}}+\beta_{13} \mathrm{ROA}_{\mathrm{t}}+\beta_{14} \mathrm{LOSS}_{\mathrm{t}}+\beta_{15} \mathrm{OWN}_{\mathrm{t}}+\beta_{16} \mathrm{FORN}_{\mathrm{t}}+\sum \mathrm{IND}+\sum \mathrm{YD}+\varepsilon_{\mathrm{t}}\end{array}$

\begin{tabular}{|c|c|c|c|c|c|}
\hline Variables & Expected Sign & Coefficient & Standard error & t-statistic & p-value \\
\hline INTERCEPT & & -1.061 & 0.188 & $-5.650 * * *$ & $<.0001$ \\
\hline$B T D$ & $+/-$ & -0.185 & 0.135 & $-1.360 *$ & 0.173 \\
\hline$G O V$ & $+/-$ & 0.070 & 0.026 & $2.690 * * *$ & 0.007 \\
\hline$B T D^{*} G O V$ & $+/-$ & 0.330 & 0.321 & 1.030 & 0.304 \\
\hline$B I G 4$ & + & 0.367 & 0.025 & $14.960 * * *$ & $<.0001$ \\
\hline FIRST & + & 0.024 & 0.027 & 0.890 & 0.373 \\
\hline$O P N$ & + & 0.247 & 0.359 & 0.690 & 0.492 \\
\hline SIZE & + & 0.382 & 0.010 & $39.260 * * *$ & $<.0001$ \\
\hline$L E V$ & + & 0.116 & 0.048 & $2.400 * *$ & 0.016 \\
\hline$L I Q$ & - & -0.010 & 0.008 & -1.280 & 0.202 \\
\hline$\widetilde{G R W}$ & + & 0.012 & 0.019 & 0.630 & 0.530 \\
\hline$C O N$ & + & -0.103 & 0.026 & $-3.950 * * *$ & $<.0001$ \\
\hline INVREC & + & 0.204 & 0.072 & $2.830 * * *$ & 0.005 \\
\hline$R O A$ & + & 0.379 & 0.138 & $2.740 * * *$ & 0.006 \\
\hline LOSS & + & 0.080 & 0.031 & $2.630 * * *$ & 0.009 \\
\hline$O W N$ & - & -0.404 & 0.066 & $-6.110 * * *$ & $<.0001$ \\
\hline FORN & + & -0.050 & 0.078 & -0.640 & 0.525 \\
\hline Year dummy & & \multicolumn{4}{|c|}{ Included } \\
\hline Industry dummy & & \multicolumn{4}{|c|}{ Included } \\
\hline$F-V A L U E$ & & \multicolumn{4}{|c|}{$144.38 * * *$} \\
\hline Adj. R2 & & \multicolumn{4}{|c|}{0.5857} \\
\hline
\end{tabular}

Note: This table provides the regression estimates of the model (3) that examines the effect of corporate governance on the association between book-tax differences (BTD) and audit hours. The model includes year and industry fixed effects based on the two-digit Korean Standard Industry Codes. T-statistics are corrected for heteroskedasticity. ***, **, and * denote statistical significance at $1 \%, 5 \%$, and $10 \%$ levels respectively, based on two-tailed test. The sample consists of 3,824 firm-year observations between 2005 and 2011. See Table 2 for all variable definitions.

Table 7 provides the results of estimating Model (4) to test our hypotheses 4. The interaction effects of corporate governance on the relationships between BTD and audit fees (LnAF) were shown to have significant positive $(+)$ association. This result means that corporate governance plays the role of increasing audit fees (LnAF) in the relationship between individual firms' BTD and audit fees (LnAF). That is, in the case of domestic listed firms, the effects of corporate governance on the relationship between BTD and audit fees (LnAF) can be regarded as supporting the viewpoint of governance rather than the viewpoint of auditors' audit risks. Therefore, firms equipped with excellent governance can be regarded as demanding differentiated audits to construct more desirable governance accordingly paying higher audit fees to auditors with high audit quality in the audit market (Park et al. 2013; Choi and Yang 2008; Kim and Kim 2012). 
Table 7. The Effect of Corporate Governance on the Association between Book-Tax Differences and Audit Fees

\begin{tabular}{|c|c|}
\hline$L n A F_{t}=$ & $\begin{aligned} & \beta_{0}+\beta_{1} B T D_{t}+\beta_{2} G O V_{t}+\beta_{3} B_{T D} \times G O V_{t}+\beta_{4} B I G 4_{t}+\beta_{5} F I R S T_{t}+\beta_{6} O P N_{t-1}+\beta_{7} S_{I Z E_{t-1}+\beta_{8} L E V_{t-1}+\beta_{9} L I G_{t-1}} \\
&+\beta_{10} G R W_{t-1}+\beta_{11} \operatorname{CON}_{t}+\beta_{12} I N V R E C_{t-1}+\beta_{13} R O A_{t-1}+\beta_{14} L O S S_{t-1}+\beta_{15} O W N_{t}+\beta_{16} F O R N_{t} \\
&+\sum I N D+\sum Y D+\varepsilon_{t}\end{aligned}$ \\
\hline
\end{tabular}

\begin{tabular}{|c|c|c|c|c|c|}
\hline Variables & Expected Sign & Coefficient & Standard error & t-statistic & p-value \\
\hline INTERCEPT & & 3.731 & 0.144 & $25.960 * * *$ & $<.0001$ \\
\hline$B T D$ & $+/-$ & 0.221 & 0.098 & $2.250 * *$ & 0.024 \\
\hline$G O V$ & $+/-$ & 0.077 & 0.020 & $3.850 * * *$ & 0.000 \\
\hline$B T D^{*} G O V$ & $+/-$ & 0.101 & 0.048 & $2.410 * *$ & 0.021 \\
\hline$B I G 4$ & + & 0.169 & 0.019 & $8.920 * * *$ & $<.0001$ \\
\hline FIRST & - & -0.064 & 0.020 & $-3.130 * * *$ & 0.002 \\
\hline$O P N$ & + & -0.032 & 0.275 & -0.120 & 0.908 \\
\hline SIZE & + & 0.375 & 0.007 & $50.460 * * *$ & $<.0001$ \\
\hline$L E V$ & + & 0.227 & 0.037 & $6.170 * * *$ & $<.0001$ \\
\hline$L I Q$ & - & -0.015 & 0.006 & $-2.640 * * *$ & 0.008 \\
\hline$G R W$ & + & 0.017 & 0.014 & 1.250 & 0.212 \\
\hline$C O N$ & + & -0.065 & 0.020 & $-3.220 * * *$ & 0.001 \\
\hline INVREC & + & 0.174 & 0.054 & $3.210 * * *$ & 0.001 \\
\hline$R O A$ & + & 0.170 & 0.101 & $1.690 *$ & 0.091 \\
\hline LOSS & + & -0.008 & 0.024 & -0.340 & 0.731 \\
\hline$O W N$ & - & -0.406 & 0.051 & $-7.970 * * *$ & $<.0001$ \\
\hline FORN & + & 0.173 & 0.060 & $2.880 * * *$ & 0.004 \\
\hline Year dummy & & \multicolumn{4}{|c|}{ Included } \\
\hline Industry dummy & & \multicolumn{4}{|c|}{ Included } \\
\hline$F-V A L U E$ & & \multicolumn{4}{|c|}{$220.08 * * *$} \\
\hline Adj. R2 & & \multicolumn{4}{|c|}{0.6861} \\
\hline
\end{tabular}

Note: This table provides the regression estimates of the model (3) that examines the effect of corporate governance on the association between book-tax differences (BTD) and audit hours. The model includes year and industry fixed effects based on the two-digit Korean Standard Industry Codes. T-statistics are corrected for heteroskedasticity. $* * *, * *$, and * denote statistical significance at $1 \%, 5 \%$, and $10 \%$ levels respectively, based on two-tailed test. The sample consists of 3,824 firm-year observations between 2005 and 2011 . See Table 2 for all variable definitions.

The control variables except for OPN, GRW, and LOSS are shown to have significant relationships with audit fees (LnAF). Concretely, the control variables BIG4, SIZE, LEV, INVREC, ROA, and FORN show significant positive $(+)$ relationships with audit fees (LnAF) and the control variables FIRST, LIQ, CON, and OWN show significant negative (-) relationships with audit fees (LnAF).

In summary, the effects of individual firms' BTD on audit fees (LnAF) showed statistically significant positive $(+)$ association, but the effects of individual firms' BTD on audit hours (LnAH) showed a negative (-) association that was not statistically significant. These study results indicate that although additional audit fees are requested for additional audit risks due to increases in individual firms' BTD, additional efforts for audits cannot be regarded to be inputted. The effects of corporate governance on the relationship between BTD and audit hours/audit fees showed a positive $(+)$ association. This means that firms with excellent governance input more audit hours as part of efforts to reduce audit risks increased due to BTD and pay additional audit fees. That is, firms with excellent governance can be regarded as making more efforts for financial reporting to continuously maintain their reliability in the market. As a result of continued efforts for securing the reliability of audit reports to give reliability to information provided to investors and relieve information asymmetry, auditors input more audit hours and request higher audit fees.

\section{CONCLUSION}

This study investigates whether auditors input additional audit hours according to the sizes of BTD and request additional audit fees for the additional audit hours. In addition, the interaction effects of corporate governance on the relationships between BTD and audit hours/audit fees were examined using the total corporate governance (TCG) scores which are data from the Korea Corporate Governance Service (KCGS). Large BTD will increase clients' inherent risks and control risks to act as a factor to increase clients' audit risks. Therefore, auditors will make efforts 
to lower the high audit risks of the clients. In this regard, verifying whether auditors actually use this information in the stages of audit procedures considering BTD is considered to have great significance in proving accounting audits' social functions.

In this study, the effects of individual firms' BTD on audit hours and audit fees were analyzed using the audit hour and audit fee data published on the business reports of firms listed on the Korea Stock Exchange (KSE) and the Korea Securities Dealers Automated Quotation (KOSDAQ) during the period 2005-2011. The empirical results of our study are as follows. First, BTD and audit hours (LnAH) show not statistically significant negative (-) association. Second, audit fees (LnAF) were shown to increase along with BTD. This can be interpreted as a result of requests for additional audit fees for increased audit risks due to individual firms' BTD. Third, the interaction effect of corporate governance on the relationship between BTD and audit hours (LnAH) show a positive $(+)$ association, but the association was not statistically significant. From the viewpoint of governance, this can be regarded as meaning that better governance inputs additional audit hours to construct more desirable governance. Fourth, the interaction effect of corporate governance on the relationship between BTD and audit fees (LnAF) show statistically significant positive $(+)$ association. This be regarded as meaning that firms with more excellent governance make more efforts for financial reporting to continuously maintain their reliability in the market.

The study contributes to the existing research in three main respects. First, this study is meaningful in that it empirically demonstrated whether auditors properly reflect BTD on audit risks. The assumption of this study that when BTD are larger, auditors will try to reduce audit risks by expanding the range of proving procedures leading to increases in audit hours and audit fees is considered as a study design that reflects audit practices. Second, this study is additionally meaningful in that it analyzed the effects of corporate governance on the relationship between BTD and audit hours/audit fees using the total corporate governance (TCG) scores presented by the Korea Corporate Governance Service (KCGS). Finally, this study empirically showed accounting audits' social proof function to reduce information risks. The empirical results of this study indicating that larger BTD are associated with higher audit fees mean that auditors make more efforts in situations where information risks are high.

Limitations of this study are as follows. First, there may be omitted variables that may additionally affect audit fees and audit hours. Second, the reliability of the audit hours announced in business reports may be problematic. Despite that the samples of audit hours and audit fees were carefully selected based on prior literature, there is a possibility that the researcher's viewpoint may have been affected the sample selection procedure.

\section{AUTHOR BIOGRAPHIES}

Hyunmin Oh, Ph.D. Candidate, Graduate School of Business, Hanyang University, and CTA working at Jae Jeong Accounting Corporation, Susan B/D, 3, Teheran-ro 6-gil, Gangnam-gu, Seoul, 06240, South Korea. E-mail: gusals@hanyang.ac.kr (Corresponding author)

Sambock Park, Ph.D. Candidate, Graduate School of Business, Hanyang University, 222 Wangsimni-ro, Seongdong-gu, Seoul 04763, South Korea. E-mail: psp96@hanyang.ac.kr (First author)

Soonwook Hong, Ph.D candidate in Accounting at Hanyang University since 2012, and works for Edaily, a daily newspaper. Soonwook Hong, Edaily, Prime Tower 19F, 48 Sogong-ro, Jung-gu, Seoul, 100-725, South Korea. Email: soonwookhong@yahoo.com

\section{REFERENCES}

Abbott, L., J. Gary, F. Peters, and S. Parker. (2003). The association between audit committee characteristics and audit fee. Auditing: A Journal of Practice \& Theory, 22, 17-32.

An, S. C. (2005). The information contents of book-tax differences. Study on Accounting, Taxation \& Auditing, 41, $299-317$.

Ayers, B., S. Laplante, and S. Mcguire. (2010). Credit ratings and taxes: the effect of book-tax differences on ratings changes. Contemporary Accounting Research, 27(2), 359-402.

Ayers, B. C., J. X. Jiang, and S. K. Laplante. (2009). Taxable income as a performance measure: The effects of tax planning and earnings quality. Contemporary Accounting Research, 26(1), 15-54.

Beaver, W. 1998. Financial Reporting: An accounting revolution. Prentice Hall. Englewood Cliffs, NJ. 
Bedard, J., and K. Johnstone. (2004). Earnings manipulation risk, corporate governance risk, and auditors' planning and pricing decisions. The Accounting Review, 79(April), 277-304.

Behn, B. K., J. H. Choi, and T. Kang. (2008). Audit quality and properties of analyst earnings forecasts. The Accounting Review, 83(2), 327-349.

Blankley, A. I., D. N. Hurtt, and J. E. MacGregor. (2012). Abnormal audit fees and restatements. Auditing: A Journal of Practice \& Theory, 31(1), 79-96.

Blaylock, b., T. Shevlin, and R. Wilson. (2012). Tax avoidance, large positive temporary book-tax differences, and earnings persistence. The Accounting Review, 87(1), 91-120.

Carcello, T. V., D. R. Hermanson, T. L. Neal, and R. R. Riley. (2002). Board characteristics and audit fees. Contemporay Accounting Research, 19(Fall), 365-385.

Charles, S. L., S. M. Glover, and N. Y. Sharp. (2010). The association between financial reporting risk and audit fees before and after the historic events surrounding SOX. Auditing: A Journal of Practice \& Theory, 29(1), 15-39.

Choi, J. H., and H. S. Yang. (2008). An examination on the relationship between corporate governance, audit fees, and audit hours. Accounting Information Research, 26(1), 59-77.

Choi, K., and I. K. Joo. (1998). A study on the adequacy of the audit fee: Analysis of the characteristics of the client and comparison with foreign countries. Korean Accounting Journal, 7(1), 61-86.

Choi, K. S., S. W.Yoo, and K. H. Kim. (2013). The effect of book-tax differences and analysts on management earnings forecast. Korean Accounting Review, 38(2), 179-213.

Cohen, J., and D. Hanno. (2000). Auditors consideration of corporate governance and management control philosophy in preplanning and planning judgements. Auditing: A Journal of Practice \& Theory, 19, 133-146.

Crabtree, A., and J. Maher. (2009). The influence of differences in taxable income and book income on the bond credit market. The Journal of the American Taxation Association, 31(1), 75-99.

Dhaliwal, D. S., C. A. Gleason, and L. F. Mills. (2004). Last-chance earnings management: Using the tax expense to meet analysts'forecasts. Contemporary Accounting Research, 21(2), 431-459

Dhaliwal, D., R. Huber, H. S. Lee, and M. Pincus. (2008). Book-tax differences, uncertainty about fundamentals and information quality, and cost capital. Working paper. The University of Arizona; University of California, Irvine.

Francis, J. (1984). The effect of audit size on audit prices. Journal of Accounting and Economics, 6(August), 133-151.

Gul, F. A., and J. Goodwin. (2010). Short-term debt maturity structures, credit ratings, and the pricing of audit services. The Accounting Review, 85(3), 877-909.

Hanlon, M. (2005). The persistence and pricing of earnings, accruals, and cash flows when firms have large. The Accounting Review, 80(1), 137-166.

Hanlon, M., and S. Heitzman. (2010). A review of tax research. Journal of Accounting and Economics, 50(2/3), 127-178.

Heltzer, W., and S. Shelton. (2011). Book-Tax differences and audit risk: Evidence from the United States. Working paper, DePaul University.

Ji, H. M., and S. H. Moon. (2006). The effect of litigation risk on audit hours and conservatism. Study on Accounting, Taxation \& Auditing, 43, 311-336.

Kim, D. Y., and Y. I. Kim. (2012). A study on effects of corporate governance on audit fees and audit hours. Korean Corporation Management Review, 19(5), 247-265.

Kim, J. O., G. S. Bae. (2006). The role of corporate characteristics to conservatism. Korean Accounting Review, $31(1), 177-202$.

Kim, Y. C., and Y. J. Byun. (2010). The effect of ownership structure on the relationship between stock option exercises and earnings management. Accounting Information Research, 28(3), 101-129.

Ko, J. k., and S. S. Yoon. (2006). Book-Tax differences and the persistence and market pricing of earnings, cash flows and accruals. Korean Accounting Review, 31(1), 27-162.

Kwon, S. Y., and M. C. Kim. (2001). Determinants of audit fee and effect of audit fee deregulation author. Korean Accounting Review, 26(2), 115-143.

Kwon, S. Y., and E. S. Ki. (2011). The effect of accruals quality on the audit hour and audit fee. Korean Accounting Review, 36(4), 27-162.

Lee, D. H., and J. U. Choi. (2013). The effect of unfaithful disclosure on audit fees and audit hours. Study on Accounting, Taxation \& Auditing, 57, 61-80.

Lee, J. H., and H. Y. Ryu. (2011). A study on the relation between corporate governance improvement and audit fee: Characteristics of outside director, ownership structure, audit committee. Korean Corporation Management Review, $18(1), 203-220$.

Lee, M. G., S. J. Chang., and H. J. Park. (2012). The effects of unfaithful disclosure on audit hours and audit fees. Korean Accounting Journal, 21(6), 1-30.

Lee, S. K., and S. J. Choi. (2012). The research about earnings management in response to the revision of tax raw using discretionary accruals and book to tax income difference. Korean Journal of Business Administration, 25(1), 249-268.

Lev, B., and D. Nissim. (2004). Taxable income, future earnings, and equity values. The Accounting Review, 79(4), $1039-1074$.

Palepu, K., J. Healy, and V. Bernard. (2000). Business analysis and valuation: Using financial statement. Cincinnati, OH: SouthWestern College Publishing.

Palmrose, Z. (1989). The relation of audit contract type to audit fees and hour. The Accounting Review, 64(July), 488-499. 
Park, J. I., and K. H. Kim. (2002). The influence of tax costs and earnings management on book-tax income differences. Korean Accounting Review, 27(2), 81-117.

Park, J. I. (2006). The association between audit committee characteristics and audit effort. Study on Accounting, Taxation \& Auditing, 43, 119-154.

Park, J. I., and K. Choi. (2009). The effect of abnormal audit fees and audit hours on discretionary accruals. Journal of Taxation and Accounting, 10(3), 257-293.

Park, J. I., J. Y. Shin, and C. W. Suh. (2013). The effect of corporate governance on the audit fees and audit hours. Working paper. The University of Chungbuk; Seoul National University.

Phillips, J., M. Pincus, and S. Rego. (2003). Earnings management: New evidence based on the deferred tax expense. The Accounting Review, 78(2), 491-522.

Schipper, K. (1989). Commentary on earnings management. Accounting Horizons, 3, 91-102.

Simunic, D. (1980). The pricing of audit services: Theory and evidence. Journal of Accounting Research, 18, 161-190.

Sohn, P. S., and H. D. Yoon. (2007). The empirical study on the relation between corporate governance and audit fees. Korean Journal of Business Administration, 20(6), 2667-2686.

$\mathrm{Xu}, \mathrm{W}$. (2010). Do management earnings forecasts incorporate information in accruals? Journal of accounting and economics, $49,227-246$.

Weber, D. P. (2009). Do analysts and investors fully appreciate the implications of book-tax differences for future earnings? Contemporary Accounting Research, 26(4), 1175-1206. 